\title{
Identification of Novel Sources of Resistance to Sclerotinia Basal Stalk Rot in South African Sunflower Germplasm
}

Gerald J. Seiler, Christopher G. Misar, Thomas J. Gulya (retired), and William R. Underwood, USDA-ARS, Red River Valley Agricultural Research Center, Northern Crop Science Laboratory, Fargo, ND 58102-2765; Bradley C. Flett, Agricultural Research Council, Grain Crops Institute, Potchefstroom 2520, South Africa; and Michelle A. Gilley, and Samuel G. Markell, North Dakota State University, Department of Plant Pathology, Fargo, ND 58108-6050

Accepted for publication 3 April 2017.

\section{Abstract}

Sclerotinia basal stalk rot (BSR) is a serious fungal disease that reduces yield of global sunflower (Helianthus annuus L.) production. Because limited chemical and biological controls of BSR are available and the present-day hybrids lack sufficient resistance, identification of new sources of resistance is needed to manage the disease in the future. A total of 59 cultivated oilseed sunflower accessions from the Agricultural Research Council, Grain Crops Institute, Potchefstroom, South Africa sunflower collection were evaluated for resistance to BSR in artificially inoculated field trials. Nine accessions from the South African sunflower collection were identified with a disease incidence less than or equal to the moderately resistant sunflower oilseed hybrid. These lines can be used in breeding programs to introgress the genes for resistance to Sclerotinia BSR into other adapted lines, providing a more efficient, durable, and environmentally friendly host plant resistance.
Cultivated sunflower (Helianthus annuus L.) is one of the most important oilseed crops in the world and is commercially produced in over 68 countries and on all continents except Antarctica (Markell et al. 2015). In the United States, sunflower was planted on approximately 1.6 million acres in 2014, with the highest concentration in the Northern Great Plains states of North and South Dakota (USDA-NASS). Two types of sunflower are grown with $75 \%$ oilseed and $25 \%$ confectionery (eatable kernels). Diseases are considered the most important biological yield-limiting factor for sunflower production in the region, and diseases caused by Sclerotinia sclerotiorum (Lib.) de Bary, are among the most common and most devastating (Block et al. 2016; Markell et al. 2015).

Sclerotinia sclerotiorum is a necrotrophic fungus capable of causing stem diseases (commonly called "white mold" or Sclerotinia wilt) on an extensive host range of more than 400 broadleaf plant species, which includes many weeds and crops (Markell et al. 2015; Schwartz 2005). The life cycle begins and ends with the sclerotia, a long-lived pathogen structure consisting of a hyphal mass covered with a hard black rind that commonly survives for 3 to 7 years in the soil. For the vast majority of these hosts, the infection process begins when the sclerotia germinate carpogenically (producing airborne ascospores released by the mushroom-like apothecia that infect the plants). Ascospores that germinate on an adequate food source, usually flowers or senescent host tissue, will produce mycelium that can invade adjacent healthy tissues, commonly leaves, petioles, and ultimately stems (Block et al. 2016; Schwartz 2005).

Corresponding author: Gerald J. Seiler; E-mail: gerald.seiler@ars.usda.gov

This article is in the public domain and not copyrightable. It may be freely reprinted with customary crediting of the source. The American Phytopathological Society, 2017.
In sunflower, $S$. sclerotiorum causes three distinctly different diseases: head rot (HR); midstalk rot (MSR); and basal stalk rot (BSR) (also called Sclerotinia wilt). While the disease cycles of sunflower MSR and HR are the same as those of S. sclerotiorum diseases on other crops, the disease cycle of BSR is unique. Root exudates from sunflowers stimulate myceliogenic germination (producing vegetative hyphae) from the sclerotia, allowing the fungus to penetrate the taproot and causing rotting of the basal stem and root tissues (Block et al. 2016; Bolton et al. 2006; Gulya et al. 1997). The first observation of BSR in a field is a sudden wilting of the entire plant (Fig. 1). Signs and symptoms include a tan to manila-colored, water-soaked, and soft lesion girdling the base of the stalk at the soil line; a white mycelium (Fig. 2); shredding of stalks; abundant small, black sclerotia in and around the lesions; and lodging (Markell et al. 2014).

Sclerotinia BSR is a serious problem in humid, temperate sunflower-growing areas, as well as in tropical and subtropical regions of the world (Block at al. 2016). This disease causes serious economic losses in sunflower globally and is one of the most important sunflower diseases in the United States (Gulya et al. 1997). Despite this, management tools for the disease are insufficient; crop rotation is of marginal use owing to the long-lived nature of the sclerotia, foliar fungicide application (commonly used for management of white mold in other crops) is not useful owing to the unique myceliogenic infection process in sunflower, fungicide seed treatments provide insufficient control, and the presentday hybrids and cultivated lines lack sufficient tolerance and resistance. Consequently, identification of new and effective sources of resistance is critical for managing this disease. No major gene(s) have been identified thus far conferring complete resistance against $S$. sclerotiorum in cultivated sunflower. Resistance to BSR is genetically complex and conditioned by multiple genes, but differences in resistance to BSR have been reported in artificially inoculated field-screening trials involving diverse 


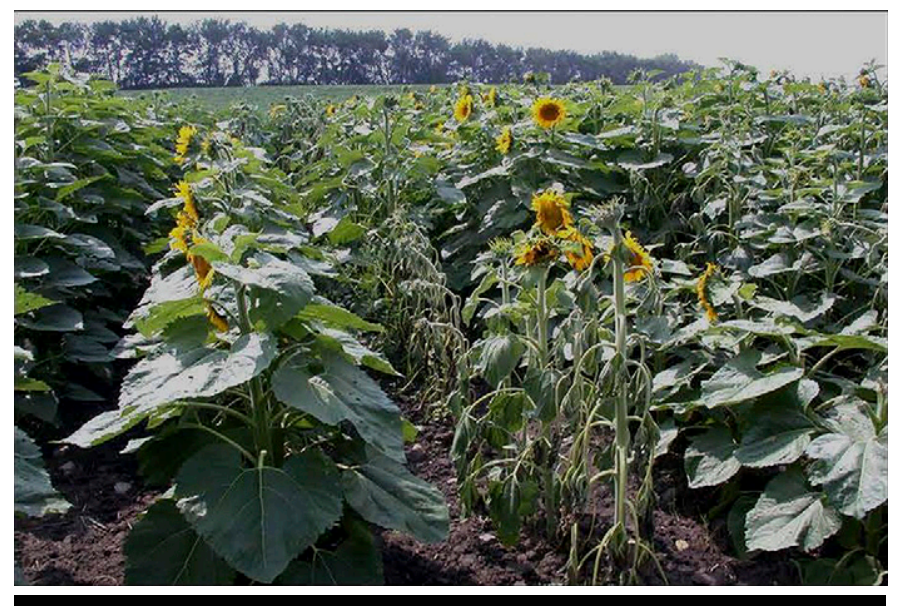

FIGURE 1

Typical symptoms of basal Sclerotinia stalk rot on sunflower, starting with terminal wilting of susceptible genotypes (right).

cultivated germplasm (Amouzadeh et al. 2013; Davar et al. 2010; Talukder et al. $2014 \mathrm{a}, \mathrm{b}$ ).

Recently, the United States Department of Agriculture, Agricultural Research Service Sunflower and Plant Biology Unit secured a germplasm exchange with the Agricultural Research Council, Grain Crops Institute in Potchefstroom, South Africa. This presented a rare opportunity to evaluate promising germplasm from another continent under different environmental conditions from those in the United States, and in particular, to address one of the most economically important diseases in both countries. This paper reports the response of sunflower germplasm from South Africa to one of the major diseases of sunflower: Sclerotinia BSR.

\section{Field Evaluation}

A total of 59 cultivated oilseed sunflower (H. annuиs L.) accessions from the Agricultural Research Council, Grain Crops Institute, Potchefstroom, South Africa sunflower collection were evaluated for resistance to BSR in artificially inoculated field trials. The evaluated germplasm represented cultivars and breeding lines in the primary gene pool (same species as cultivated sunflower) that can be used for sunflower improvement. A randomized complete block design with two replications was used to evaluate germplasm at the North Dakota State University Research and Extension Center, Carrington, ND, and test plots of Cenex Harvest States (CHS, Inver Grove Heights, MN) at Grandin, ND, in 2014, and Carrington, ND, in 2015. All fields were previously planted to cereal grains. Internal controls included a susceptible commercial oilseed hybrid, Mycogen 270 (Dow AgroSciences, Indianapolis, IN), and a moderately resistant oilseed hybrid, Croplan 305 (Land O'Lakes, Arden Hills, MN). Single-row plots $6 \mathrm{~m}$ long, with $75 \mathrm{~cm}$ between rows, were thinned to 25 plants per row (accessions and checks) and maintained using standard agronomic practices with no confounding fungicide treatments. In 2014, the trial at Grandin was planted on 23 May and inoculated on 3 July, and the trial at Carrington was planted on 4 June and inoculated 10 July, while in 2015, the Carrington trial was planted on 4 June and inoculated on 9 July. The inoculum consisted of dried Proso millet (Panicum miliaceum L.) infected with mycelial $S$. sclerotiorum isolate NEB-274 (provided by M. Boosalis, Department of Plant Pathology, University of Nebraska, Lincoln) with $90 \mathrm{~g}$ of inoculum placed $10 \mathrm{~cm}$ from the row at a depth of $5 \mathrm{~cm}$ using a GPS-guided,

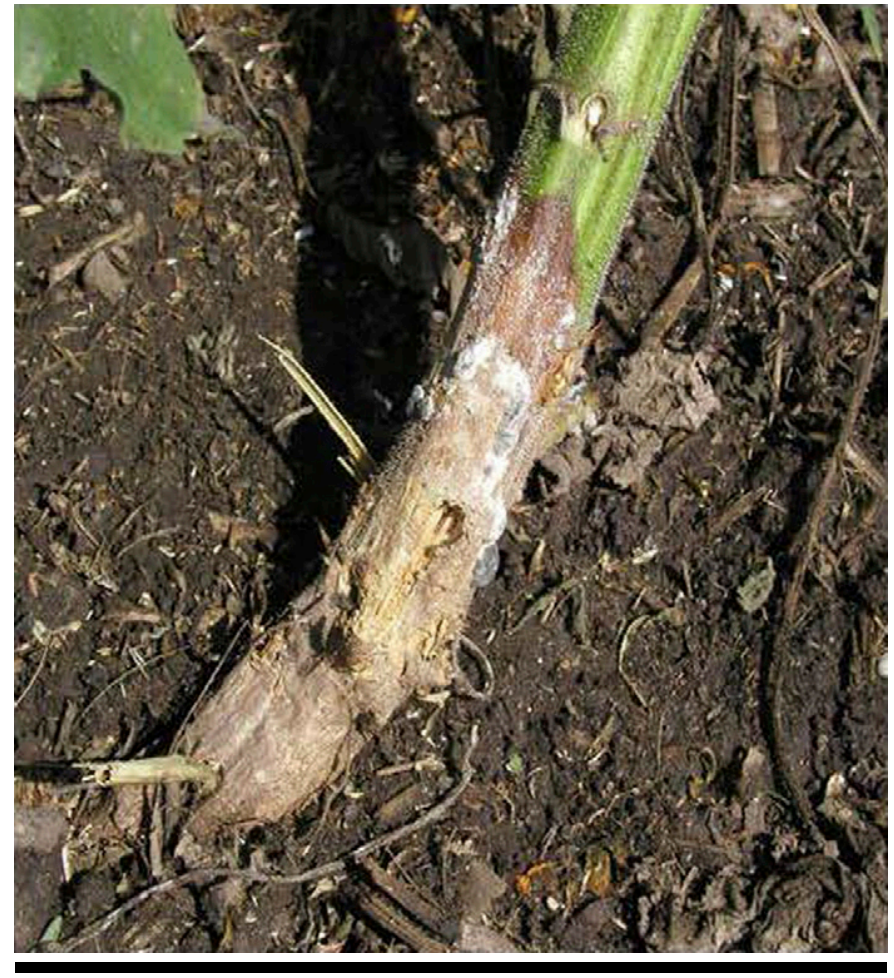

FIGURE 2

Typical symptoms of basal Sclerotinia stalk rot on sunflower with a tan to manila basal lesion at the soil line and lower stem with white mycelium.

tractor-mounted, four-row, electrically driven Gandy (Model M902EM-R, Owatonna, MN) applicator with disk openers (Gulya 2004). Plots were artificially inoculated at the V-6 growth stage (Schneiter and Miller 1981). The trials were carried out under rainfed conditions. Seasonal precipitation (June through September, 120 days) was adequate with at least $230 \mathrm{~mm}$ at all locations in both years.

\section{Disease Rating and Statistical Analysis}

Visual evaluation of the artificially inoculated plots for disease incidence (DI) of Sclerotinia basal stalk rot was conducted on 16 September 2014 at Grandin, and on 2 October 2014 and 1 October 2015 at Carrington. Disease incidence (DI) percent (number of plants infected/number of plants in the plot) was recorded at the R-9 growth stage (Schneiter and Miller 1981), which is considered physiological maturity, prior to a killing frost. Stalks with a tan to manila basal lesion with white mycelium or black sclerotia at the soil line, or wilted plants with stalk shredding or lodging with black sclerotia present, were considered infected (Gulya 2004, Markell et al. 2014). Data were analyzed using the PROC GLM procedure (SAS version 9.4, SAS Institute Inc., Cary, NC) and Fisher's protected LSD at the 5\% probability level for mean comparisons. An analysis of variance of the disease incidence (visual evaluation) determined that there were significant differences among the accessions, but there was no significant accession $\times$ location interaction indicating that the genotypes were reacting similarly in all environments so the data were combined over the three locations. There was also no significant block effect at any of the locations.

\section{Sources of Resistance}

Basal stalk rot symptom development was typical and uniform with no other significant disease symptoms evident in the plots. 
TABLE 1

Basal stalk rot incidence of $\mathbf{5 9}$ sunflower accessions originating from South Africa in three inoculated field trials

\begin{tabular}{|c|c|c|}
\hline \multicolumn{2}{|c|}{ Identification w } & \multirow{2}{*}{$\begin{array}{c}\text { Basal stalk } \\
\text { rot } \% \text { incidencey }\end{array}$} \\
\hline Accession No. & Description & \\
\hline KP 401 & NRG 1255 & $75 \mathrm{a}^{\mathrm{z}}$ \\
\hline KP 206 & Estanzvela 75 & $66 \mathrm{ab}$ \\
\hline KP 278 & CMS White Colored & $62 \mathrm{a}-\mathrm{c}$ \\
\hline KP 18 & Kortus & 58 a-d \\
\hline KP 410 & Potch Rf Comp & 58 a-d \\
\hline $\begin{array}{l}\text { Susceptible } \\
\text { check }^{x}\end{array}$ & Hybrid Mycogen 270 & 58 a-d \\
\hline KP 615 & Self Mogrdlyn & 57 a-e \\
\hline KP 375 & Bol $774 \mathrm{OP}+\mathrm{M}$ & 55 a-f \\
\hline KP 85 & Romsun 59 & 54 a-f \\
\hline KP 441 & Smena & $53 \mathrm{a}-\mathrm{g}$ \\
\hline KP 538 & Rakad & $52 \mathrm{a}-\mathrm{h}$ \\
\hline KP 62 & Romsun 42 RM & $49 \mathrm{~b}-\mathrm{i}$ \\
\hline KP 513 & Numa-1 O8A-152 & $46 \mathrm{~b}-\mathrm{j}$ \\
\hline KP 163 & Romsun 52 & $45 \mathrm{~b}-\mathrm{k}$ \\
\hline KP 8 & Pole-Star & $45 \mathrm{~b}-\mathrm{k}$ \\
\hline KP 193 & CGRF & $45 \mathrm{~b}-1$ \\
\hline KP 175 & Charata 15 & $43 \mathrm{~b}-\mathrm{m}$ \\
\hline KP 405 & Tryson G-Plasm-08-A-96 & 42 b-n \\
\hline KP 479 & Charata INTA & $39 b-o$ \\
\hline KP 248 & Short Petiole & $39 \mathrm{~b}-\mathrm{o}$ \\
\hline KP 199 & Gepe & $39 \mathrm{~b}-\mathrm{o}$ \\
\hline KP 79 & Romsun 180 NVT & $38 \mathrm{c}-\mathrm{o}$ \\
\hline KP 416 & RK 74 Voelkos & $38 \mathrm{c}-\mathrm{o}$ \\
\hline KP 78 & Romsun 18 VT & $38 \mathrm{c}-\mathrm{o}$ \\
\hline KP 37 & HS-20 & $37 \mathrm{c}-\mathrm{o}$ \\
\hline KP 189 & Prowess & $37 \mathrm{c}-\mathrm{o}$ \\
\hline KP 172 & Rust Comp B & $37 \mathrm{c}-\mathrm{o}$ \\
\hline KP 81 & Romsun 200 NVT & $36 \mathrm{c}-\mathrm{o}$ \\
\hline KP 257 & Gabureinta & $36 \mathrm{c}-\mathrm{o}$ \\
\hline KP 82 & Romsun 51 & $36 \mathrm{c}-\mathrm{o}$ \\
\hline KP 42 & INRA 4701 & $36 \mathrm{c}-\mathrm{o}$ \\
\hline KP 80 & Romsun $20 \mathrm{VT}$ & $35 \mathrm{c}-\mathrm{o}$ \\
\hline KP 56 & Estanzvela-Yatay & $34 \mathrm{c}-\mathrm{o}$ \\
\hline KP 273 & PGRIL II & $34 \mathrm{c}-\mathrm{o}$ \\
\hline KP 421 & RCM 74 & $34 \mathrm{c}-\mathrm{o}$ \\
\hline KP 10 & Disco Volante & 33 d-o \\
\hline KP 114 & Cakinskij & $33 \mathrm{~d}-\mathrm{o}$ \\
\hline KP 62 & Mozambique-5 & 33 d-o \\
\hline KP 181 & Felix 5165 & 32 d-o \\
\hline KP 93 & Sputnik 4-6-1-1 & 31 d-p \\
\hline KP 14 & Uniimk-Gun Kelman & 30 e-p \\
\hline KP 27 & Jubuennij & 29 f-p \\
\hline KP 67 & HS 80 CRM & 29 f-p \\
\hline KP 94 & Sputnik 26-4-2 & $28 \mathrm{f}-\mathrm{p}$ \\
\hline KP 9 & Pehuen INTA & $26 \mathrm{~g}-\mathrm{p}$ \\
\hline KP 205 & Cuzv & $26 \mathrm{~g}-\mathrm{p}$ \\
\hline KP 121 & Record & $25 \mathrm{~h}-\mathrm{p}$ \\
\hline KP 1249 & Annemi & 23 i-p \\
\hline KP 1248 & Gigi & $21 \mathrm{j}-\mathrm{p}$ \\
\hline KP 609 & Smyrna & $20 \mathrm{j}-\mathrm{p}$ \\
\hline KP 6 & Zelenka & 19 j-p \\
\hline
\end{tabular}

(continued in next column)

\begin{tabular}{|c|c|c|}
\hline \multicolumn{3}{|c|}{$\begin{array}{c}\text { TABLE } 1 \\
\text { (continued from previous column) }\end{array}$} \\
\hline \multicolumn{2}{|c|}{ Identification $\mathbf{w}$} & \multirow{2}{*}{$\begin{array}{c}\text { Basal stalk } \\
\text { rot\% incidence }\end{array}$} \\
\hline Accession No. & Description & \\
\hline $\begin{array}{c}\text { Resistant } \\
\text { check }^{x}\end{array}$ & Hybrid Croplan 305 & $18 \mathrm{j}-\mathrm{p}$ \\
\hline KP 15 & Wierenga & $17 \mathrm{k}-\mathrm{p}$ \\
\hline KP 235 & V1343-55-394 & $17 \mathrm{k}-\mathrm{p}$ \\
\hline KP 487 & Trysun 15 & $151-p$ \\
\hline KР 309 & Tordillo & $151-p$ \\
\hline KP 31 & HS 53 & $14 \mathrm{~m}-\mathrm{p}$ \\
\hline KP 512 & Enana & $14 \mathrm{~m}-\mathrm{p}$ \\
\hline KP 1251 & Belinda & $13 n-p$ \\
\hline KP 679 & PRS 7RF & 12 o-p \\
\hline KP 604 & Leaf-spot Rest 3 & $3 \mathrm{q}$ \\
\hline
\end{tabular}

${ }^{w}$ South African Agricultural Research Council accession number and identification.

${ }^{\mathrm{x}}$ Two accessions served as checks (bold): one susceptible hybrid, Mycogen 270; and one moderately resistant hybrid, Croplan 305.

${ }^{y}$ Disease incidence is the number of infected plants divided by the total number of plants in the plot rated at the R9 growth stage.

${ }^{\mathrm{z}}$ Means within a column with the same letter(s) are not significantly different at the 5\% probability level based on the Fisher's protected LSD test. Data were combined over the three trials.

The BSR susceptible check Mycogen 270 had a mean DI of 58\%, while the moderately resistant check Croplan 305 had a DI of $18 \%$ (Table 1). Accession KP 401 was the most susceptible with $75 \%$ DI, while KP 604 was the most resistant with a DI of $3 \%$. Thirty-eight accessions ranging from 32 to $75 \%$ DI were not significantly different from the susceptible check Mycogen 270. Twenty accessions ranging from 12 to $30 \%$ DI were statistically similar to the moderately resistant check Croplan 305 . At the peak of the BSR infection, nine accessions (KP15, KP235, KP487, KP309, KP31, KP512, KP1251, KP679, and KP604) had a DI lower than the resistant check with $18 \%$. Several of these accessions could serve as the starting point for identifying novel sources of resistance to BSR disease, especially accession KP 604.

The pattern of DI for BSR in the South African accessions was somewhat similar to a study by Gulya et al. (2008) in which the DI for the susceptible hybrid check (Mycogen 270) was 68\%, and the resistant hybrid check (HA 412 X RHA 409) was $20 \%$. In that study, only four hybrids of the 75 commercial hybrids tested (5\%) had a numerically similar DI compared with the resistant check, but were not significantly different (Gulya et al. 2008). In a recent study by Talukder et al. (2014a), 260 plant introduction (PI) lines from the USDA-ARS, National Plant Germplasm System sunflower collection were evaluated for BSR; thirty-six (14\%) of the PIs had similar or lower levels of BSR incidence compared with the resistant hybrid check Cropland 305 with 22\% DI. In the current study, $15 \%$ of the accessions had similar or lower levels of BSR incidence compared with the resistant hybrid check. Since there is no source of complete resistance to BSR, the extremely low DI in accession KP604 (3\%) is encouraging, since resistance is highly quantitative, offering breeders the opportunity to add a major QTL (quantitative trait locus) gene for better controlling BSR. The value of South African germplasm may lie in the diversity of the germplasm being developed in a different environment, broadening the genes for resistance to BSR. 


\section{Conclusions}

Sclerotinia basal stalk rot is one of the most devastating sunflower diseases in the world and current management tools are grossly insufficient (Gulya et al. 1997; Markell et al. 2015; Block et al. 2016). In this study, we identified a total of nine accessions from the South African sunflower collection with DI less than or equal to the most moderately resistant sunflower hybrid, and one accession KP604 that is particularly promising due to its extremely low DI. These lines can be used in breeding programs to introgress the genes for resistance to Sclerotinia BSR into other adapted lines providing a more efficient, durable, and environmentally friendly host-plant resistance.

\section{Acknowledgments and Disclaimer}

This research was supported by the USDA-ARS CRIS Project 306021000-039-00D and Specific Cooperative Agreement 58-5442-2-206 between USDA-ARS and North Dakota State University, funded by the USDA-ARS, National Sclerotinia Initiative.

We would like to thank Marjorie Olson, Lisa Brown, and Angelia Hogness for assistance with the field testing. Mention of trade names or commercial products in this report is solely for the purpose of providing specific information and does not imply recommendations or endorsement by the U.S. Department of Agriculture. The USDA is an equal opportunity provider and employer.

\section{Literature Cited}

Amouzadeh, M., Darvishzadeh, R., Haddadi, P., Abdollahi Mandoulakani, B., and Rezaee Danesh, Y. 2013. Genetic analysis of partial resistance to basal stem rot (Sclerotinia sclerotiorum) in sunflower. Genetika 45:737-748.

Block, C. C., Rashid, K. Y., and Gulya, T. J. 2016. Sclerotinia root rot, basal stalk rot, amd wilt. Pages 57-59 in: Compendium of Sunflower Diseases and Pests. R. M. Harveson, S. G. Markell, C. C. Block, and T. G. Gulya, eds. American Phytopathological Society, St. Paul, MN.
Bolton, M. D., Thomma, B. P. H. J., and Nelson, B. D. 2006. Sclerotinia sclerotiorum (Lib.) de Bary: Biology and molecular traits of a cosmopolitan pathogen. Mol. Plant Pathol. 7:1-16.

Davar, R., Darvishzadeh, R., Majd, A., Ghosta, Y., and Sarrafi, A. 2010. QTL mapping of partial resistance to basal stem rot in sunflower using recombinant inbred lines. Phytopathol. Mediterr. 49:330-341.

Gulya, T. J. 2004. An inoculation method for Sclerotinia stalk rot. Pages 1-6 in: P. of the 26th Sunflower Res. Workshop, Nat. Sunflower Assoc., Mandan, ND.

Gulya, T. J., Radi, S., and Balbyshev, N. 2008. Large scale field evaluations for Sclerotinia stalk rot resistance in cultivated sunflower. Pages 175-179 in: P. of the 17th Int. Sunflower Conf., Cordoba, Spain. L. Velasco, ed. International Sunflower Association, Paris, France.

Gulya, T. J., Rashid, K. Y., and Masirevic, S. M. 1997. Sunflower diseases. Pages 263-279 in: Sunflower Technology and Production. A. A. Schneiter, ed. Crop Sci. Soc. of Am., Madison, WI.

Markell, S., Harveson, R., Block, C., and Gulya, T. 2014. Sclerotinia wilt/basal stalk rot. Pages 23-24 in: Sunflower Disease Diagnostic Series. S. Markell, R. Harveson, C.R. Block, and T. Gulya, eds. Coop. Ext. Serv. Pub. PP-1727-11. North Dakota State Univ., Fargo, ND.

Markell, S. G., Harveson, R. H., Block, C. C., and Gulya, T. J. 2015. Sunflower diseases. Pages 93-128 in: Sunflower: Chemistry, Production, Processing and Utilization. E. M. Force, N. T. Dunford, and J. L. Salas, eds. Am. Oilseed Chem. Soc., Urbana, IL.

Schneiter, A. A., and Miller, J. F. 1981. Description of sunflower growth stages. Crop Sci. 21:901-903.

Schwartz, H. F. 2005. Infectious diseases, white mold. Pages 44-46 in: Compendium of Bean Diseases. H. F. Schwartz, J. R. Steadman, R. Hall, and R. L. Forster, eds. American Phytopathological Society, St. Paul, MN.

Talukder, Z. I., Hulke, B. S., Marek, L. F., and Gulya, T. J. 2014a. Sources of resistance to sunflower diseases in a global collection of domesticated USDA plant introductions. Crop Sci. 54:694-705.

Talukder, Z. I., Hulke, B. S., Qi, L. L., Scheffler, B. E., Pegadaraju, V., McPhee, K., and Gulya, T. J. 2014b. Candidate gene association mapping of Sclerotinia stalk rot resistance in sunflower (Helianthus annuus L.) uncovers the importance of COI1 homologs. Theor. Appl. Genet. 127: 193-209. 